\title{
A SURVEY OF IRAN's SOCIAL STRUCTURE In THE TranSITION FROM THE SASSANID TO THE EARLY ISLAMIC ERA FROM THE MANUSCRIPT AND ARCHAEOLOGICAL EVIDENCE
}

\author{
TARİHî YAZMALAR VE ARKEOLOJÍK BULUNTULAR IȘIĞINDA SASANÎ DÖNEMİ'NDEN \\ ERKEN İSLAM DÖNEMI'NE GEÇISS SÜRECINDE İRAN'IN SOSYAL YAPISI \\ ÜZERINE BIR ARAȘTIRMA
}

\section{ALİ AARAB ${ }^{*}$}

\begin{abstract}
Iran's social structure in the transition period from Sassanid rule to early Islam is of great importance. The social structure of the Sassanid period was of a hierarchical kind that placed too many social and economic burdens on society's lower classes. This paper examines through the use of historical texts the role of the Sassanid social structure and its pressure on the process of conversion to Islam by Iranians. The related literature shows this was one of the main reasons that Iranians accepted Islam, due to the modification of the social structure by the Muslims of early Islam who exerted effort to this end and this case can be investigated through the use of historical manuscripts and archaeological finds. However, the modified conditions in the following period took a different form that brought about the formation of other social classes which included classes formed on the basis of race and religion. Nevertheless, the landowner class obtained much power during this period which increased the pressure upon the lower classes who were mostly farmers. Thus, in the era of early Islam the same pressure from the upper class remained over the farmers who were a class having a most significant population.
\end{abstract}

Keywords: Social Structure • Sassanid Era • Early Islamic Period • Manuscripts • Archaeological Evidence
Öz: Sasanî egemenliğinden erken İslam Dönemi'ne geçiş sürecinde İran'in sosyal yapısı büyük bir önem arz etmektedir. Sasanî Dönemi’ndeki sosyal yapı toplumun alt sınıfı üzerinde çok fazla sosyal ve ekonomik baskı uygulayan hiyerarşik bir düzendedir. Bu makale, Sasanî Dönemi'nin sosyal yapısındaki rolü ve tarihî metinleri temel alarak İranlılar nezdinde İslam'ın kabulü hususundaki baskııı incelemektedir. İlgili literatür, İranlıların İslam'ı kabul etmesinin ana nedenlerinden birisinin, bu durumun sonlandırılması için efor sarf eden erken İslam Dönemi Müslümanları tarafından sosyal yapının değiştirilmesi nedeniyle meydana geldiğini ve bu durumun tarihî el yazmaları ve arkeolojik buluntular vasitasıyla incelenebilir olduğunu ortaya çıkarmaktadır. Lâkin ilerleyen dönemde değişen şartlar farklı bir hâl alarak diğer sosyal sınıfların oluşumuna sebebiyet vermiștir, buna irk ve din tabanlı sinıflar da dâhildir. Bununla birlikte, çoğunluğu çiftçi olan alt sınıflar üzerindeki baskıyı artıran bu süreç içinde toprak sahibi olan sınıf güç kazanmıştır. Böylece, İran'in erken İslam Dönemi'nde üst sinıflarca yapılan aynı baskı, kayda değer bir nüfusu barındıran çiftçiler sınıfı üzerinde bâki kalmıștır.

Anahtar Kelimeler: Sosyal Yapı • Sasani Dönemi - Erken İslam Dönemi • Tarihsel Yazmalar • Arkeolojik Buluntular

\section{Introduction}

The term 'social class' refers to a part of the society different from other segments of society in terms of shared values, dignity and rank, social activities, amount of money, wealth and personal belong-

\footnotetext{
* MA., University of Tehran, Department of Archaeology, Tehran. ali.aarab@ut.ac.ir
} 
ings, as also manners and etiquette'. In addition to the term 'social class', another term is also employed, 'caste'. Biro defines 'caste' as a closed social group in which inbreeding exists and the related people of the caste have their own special professions, customs, beliefs, rituals, and traditions. No one is allowed to move from one caste to another. People are born in one caste and live to their lives' end in the same caste without any change ${ }^{2}$. Based upon Biro's definition, it seems that the term caste system pertains more to Sassanid society than social class. In a caste system, upward mobility and change is not impossible ${ }^{3}$. Michel Panoff and Michel Bern states that a caste system refers to a group that has restricted boundaries and conducts specific performances in the realm of religious, legal, economic, and social rituals. They also have specific criteria for that group of principles that prevent social relationships between one caste and another, which are in turn surrounded and hidden by a purification ideology, especially blood purification ${ }^{4}$. Some scholars consider caste a closed community system that has three main characteristics: Membership, marriage, and profession ${ }^{5}$. One of the most well-known of caste systems is that of the Hindu community ${ }^{6}$. Max Weber stated the influence of three factors is the reason for this type of social stratification these are: Economic (the ownership of wealth), politics (power distribution), and social credit (Status and dignity) ${ }^{7}$. Islam believes in equality and brotherhood in society, in contrast to the hierarchical social structure of the Sassanid era. Accordingly, through studying this feature in Islamic society and the hierarchical society of the Sassanid era, this research investigates the social structure of Iran during this significant transitional period.

The Sassanid kings established a religious monarchy from the beginning of their rule and Sassan the founder of this dynasty, was the grandfather of Ardeshir Bababkan, one of the Zoroastrian priests of the Anahita temple. ${ }^{8}$. The integration of religion and politics in this era was to such a degree that the great Iranian poet Ferdowsi relates in his Shahname that religion and politics were so integrated that you thought they lived in one tent, and that no religious man was without power and no king was without religion?. During 1500 years of pre-Islamic history, Iran did not remain unchanged. Changes in the direction of evolution are observable in terms of tools, production methods, the social classes, the regime, and the degree of cultural evolution. In consequence, the dynastic or "Wais" system based upon patriarchal traditions gradually declined and the caste and centralized state system under the rule of one king took its place. There appeared cities, bazaars, craftsmen, trade, monetary relations and slavery and, over the course of time, the signs of a feudal aristocratic society with its sumptuous traditions emerged in this society. All of these social phenomena continued to be sustained for some time after the establishment of Islam in $\operatorname{Iran}^{10}$.

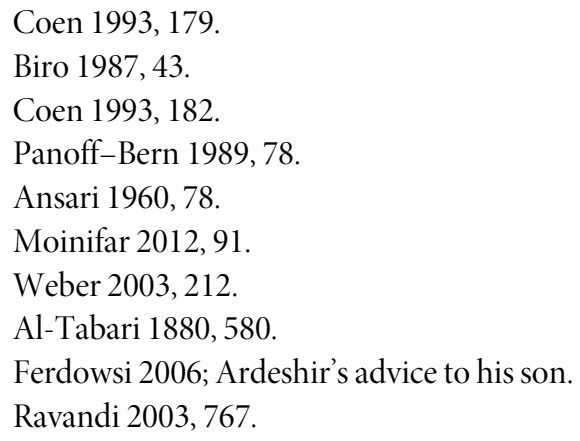




\section{Historical Texts and Social Classes during the Sassanid Era and Early Islam}

Following on from the social structure of the Parthian era, the Sassanid social structure appeared and continued until the fall of the monarchy. One of the most important available written sources showing the religious-historical aspects of Sassanid Zoroastrian society is the book of Avesta. This book presents cases concerning the social classes: "What are the four professions? Fire keepers, warriors, farmers, and artisans whose duties are directed by good words, good thoughts, and goods deeds. Good manners with people would lead righteousness to spread all over the world"11. In another part he talks about the four professions and five classes in the society.

Also in Zamya Yasht it is said that as long as the mountains are stretched, equally the Creator has divided and granted them to leaders, warriors, farmers, and ranchers ${ }^{12}$. In other parts of the Avesta, three classes are mentioned: Athorvan, Re'eh Ashtar, and Asterieh ${ }^{13}$. These groups are presented differently in the Pahlavi language as: Asrouk, Arteshtareh, and Asterie, meaning: fire keeper, warrior, and farmer which also included artisans ${ }^{14}$. The juridical system of the Sassanid era that dictated the caste system, was established on the foundation provided by the Avesta, its interpretations, and the consensus of sages. Therefore, the status of the Avesta as the Zoroaster philosophy of thought is quite evident and vivid within the legal system and in the social classes of the Sassanid period.

The Rigveda is a book very close to and similar to the Avesta, in which the social classes are described. It mentions them as: Brahman (priests), Rajanieh (rulers and aristocrats), and Vayzieh (farmers, and artisans $)^{15}$. From Doumezil's point of view, this tripartite stratification had existed in practice from before the separation of the Indo-Iranian tribes and had been a part of the religious principles of the Aryan tribes ${ }^{16}$.

On the other hand, throughout the Gatha manuscript, in many instances the book talks about goodness against evil, blackness against purity, and darkness against light and these can be considered as being one of the major perspectives and beliefs of the Zoroastrian religion. As some scholars consider the existence of purity and impurity as one of the main elements of the caste systems in India ${ }^{17}$, the existence of such a view can also be considered as one of the reasons for the formation of social classes and castes and which also had a significant role in the religion, economy, and politics. In this respect, stressing the social classes and remaining within one's class in Zoroastrian thought can be mentioned, this being a definition of divine and social justice ${ }^{18}$, and also social order-social stability. This is because according to Zoroastrian philosophy, one of the three major characteristics after wisdom is justice. Accordingly, for social and divine justice and order, each social class was led in a direction so that no one desired to leave one class in order to ascend to an upper one, which as asystem is very similar to the caste system. In relation to the social classes, the term "Pishtareh" is used in the Avesta which means color. This does not refer to differencein skin color, but to the differences in the color of clothing worn by the different classes of the society. The priests dressed in

11 Pour Davoud -Frahwashi 1998, Yasna 19, Hat 17.

12 Pour Davoud 1988, Faghare 7.

13 Benveniste 1932, 119-123.

14 Pour Davoud - Frahwashi 1998, Yasna 211.

15 Saeidi Madani 2011, 161.

16 Dumezil 1958, 11-17.

17 Dumont 1990, 76.

18 Karimian 2008, 100. 
white, the warriors dressed in purple and reddish, and the farmers dressed in indigo.

Iranian society during the Sassanid era was based upon two pillars, of ownership and blood and the regulations and limits separating the nobles and aristocrats from the general public. The life of the nobles in terms of clothing, food, residence, steed, mates, and servants was incomparable with the life of the farmers who constituted almost eighty percent $(80 \%)$ of the country's inhabitants ${ }^{19}$. Considering the values and norms governing this Sassanid era stratification through making efforts for blood purity preservation, preventing the displacement of people from their places and the lack of social mobility, inter-group marriages among the upper strata especially incest, family inherited membership, and even occupation, one may conclude that the system was very similar to the caste system, although not fully complying with $\mathrm{it}^{20}$.

In regard to the social classes of the Sassanid era, Ardeshir divided the people into four groups: first are the cavalry who were nobles (sons of the kings), second are the sages and fire temple servants, third are the writers and astronomers, and the fourth are the artisans. Ferdowsi refers to four groups in his book, these are termed: Kartouzian (priests), Nisarian (warriors), Besoodi (farmers and shepherds), and Ahtoukhvashi (artisans); however, he attributed the emergence of them to King Jamshid. By juxtaposing what historians and authors asserted regarding the social classes during the Sassanid era, one can conclude that there were five strata in the Sassanid era: the king and the aristocrats, priests, army men, writers (scribes), and the wealth producers.

Leaving the social class in which one was born would bring about many problems for Sassanid society and because of this people found a religious role within a social class so that they would

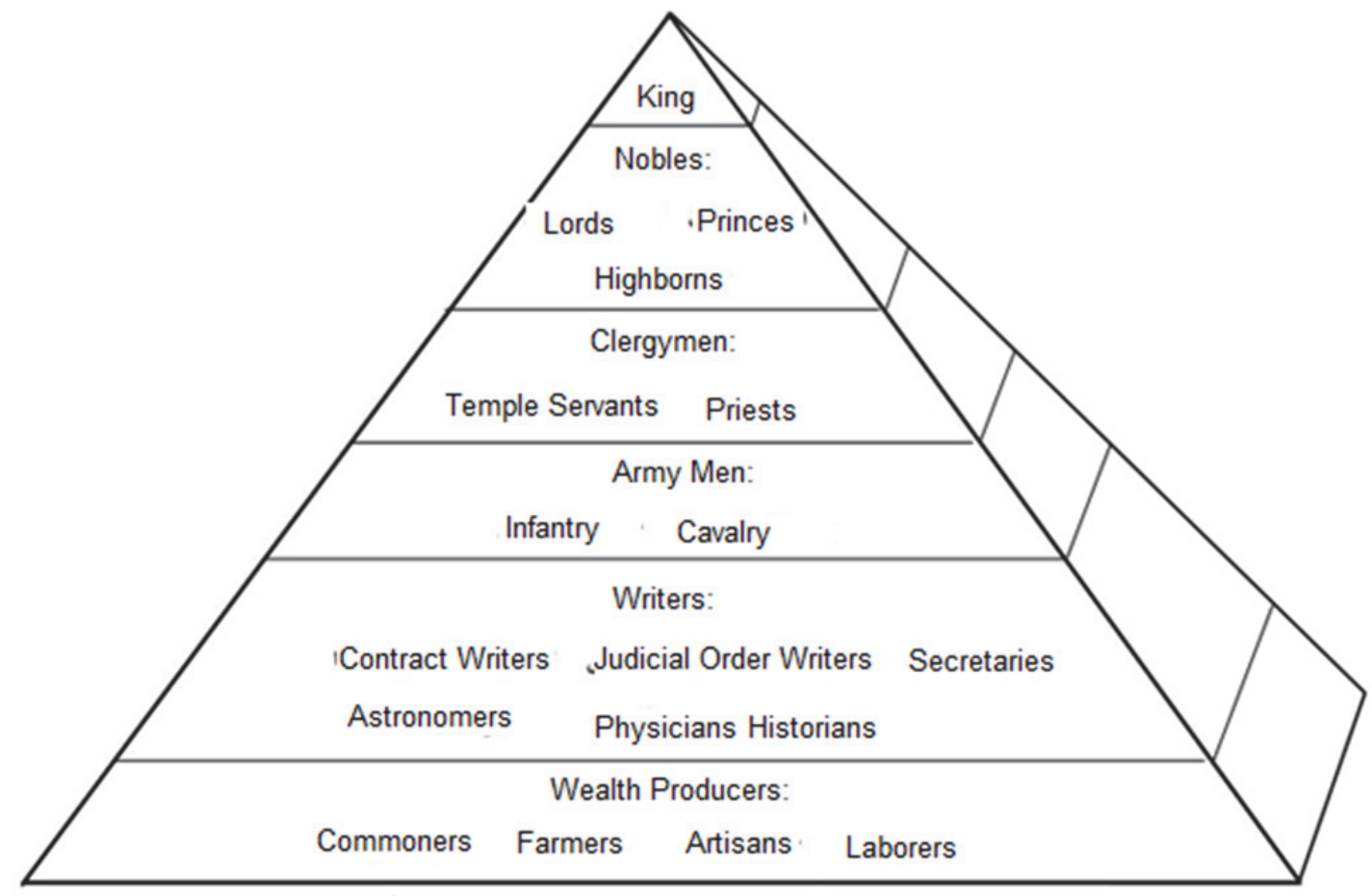

Fig 1. Social Organization in Sassanid Iran

19 Ravandi 2003, 648.

20 Sasanpur - Moftakhari 2012, 81. 
remain where they were without making any protest. Otherwise, the evil forces would dominate the people, becausethe strata of society and the rituals would be disturbed, chaos would emerge, and the emergence of ignorant clergy, devastating warriors, and disorderly farmers and artisans would bring about the reign of injustice, the lie, and chaos, which would take over the world ${ }^{21}$. Following this same way of thinking, this stratification system continued strongly in Iranian society and Ferdowsi expresses this belief in this way: a warrior and a craftsman should not seek art in the same direction, one is a mace-bearer and the other is alabourer. There is a profession for every man in each social class that is worthy of him ${ }^{22}$. It is also cited from Ardeshir-e Babakan that nothing is more influential in the destruction of a country and the transference of power than the transference of classes from their strata, a course in which the grandees fall and are replaced by the ignoble and vice versa.

As mentioned above, the Sassanid kings emphasised religious thought and philosophy in many ways and used the Zoroastrian religious philosophy in their favor in order to create social classes. It is quite possible that a social institution in the process of its growth and development prioritizes a certain philosophy to justify its existence and for the Sassanid kings ${ }^{23}$, this was the philosophy of the social classes articulated through Zoroastrianism.

The most significant point of Arab history is its dual structure. The existence of two groups (both bedouin and sedentary) alongside each other with varying ranks is quite important because it shows that in Arabia before Islam two different social classes existed. At the beginning of the seventh century A.D. in Yathrib (Medina) and among the Arab nomads, class differences and financial inequalities were evident and the conflict of interests between tribal elders and the ordinary people had brought about unprecedented tension and discord, for ending of which a centralized unitary state was necessary. By establishing such a state, they not only found new economic opportunities but also were able to end the conflicts and animosities amongst themselves. To achieve this goal, a new religious belief which was based on monotheism and fraternity was needed, to replace hostility between the tribes. Similar to the Medieval period that knew only one ideology, religion, as such the new religion of Islam put an end to these problems ${ }^{24}$.

In the course of the Musim Arab invasion, they first conquered the city of Hirah. With this conquest the route to southern Iraq and the plains of Khuzestan was opened to the armies of Islam. From the twelfth century onward, the people of Hirah had a spying role for the Muslims against the Sassanids due to which the city gained great importance. At the time of the Arab invasion as mentioned above, severe class differences within Iranian society existed and rural and urban people were shattered by heavy taxes, while the upper classes, the nobles and clergy enjoyed various privileges. The noteworthy point is that no consensus existed between these aforementioned classes; in other words, on one side the military nobility and leaders of the clergy and on the other side the civil servants (writers) and farmers were in conflict with each other. Even after the Muslim Arab invasion and their rapid advance towards important regions, the Sassanid leaders never attempted seriously to address and stop the unnecessary formalities and arrogance that threatened their own existence. In other words, the arrival of Islam had the form of a revolution that challenged the religious and

\footnotetext{
Karimian - Moghimi 2014, 40.

Kazazi 2006, 56.

Ansari 1960, 16.

Ravandi 1977, 12.
} 
social system as also economic relations in society including both urban and rural ones ${ }^{25}$. The acceptance of Islam in Iran was a gradual process and the spread of the new religion differed according to the region and various social classes that existed in that place ${ }^{26}$. It changed people's social and family life.

Iran's economy which was based upon agriculture continued after the arrival of Islam although there were changes regarding the way of taxation. The immigration of different segments of Arab Muslims began from the time of second Caliph Omar Ibn-Al-Khattab. He also banned marriages between Arabs and Iranian women and captives ${ }^{27}$. Zoroastrian priests who were not independent of the previous Sassanid government quickly disappeared from the upper social strata as a consequence of the Caliphate's military domination. Due to not being of Arab descent, the lords were considered second-class citizens and the clergy paid tribute to the Arab Muslims to remain in their religion ${ }^{28}$. Paying the tribute had to be accompanied by signs of inferiority. When paying the tribute, a tag made of lead was attached to the paying person as the receipt and as a sign of being a Zoroastrian. In terms of the previous religion the class consisting of artists and artisans because of the nature of their profession were considered unclean; therefore, unsurprisingly the new religion was more pleasant to these classes. It can be said that Iran in early Islam had a cluttered and chaotic status; the social class walls had collapsed and profound changes in the distribution of power and ownership emerged and in consequence no sublimity and excellence could be expected of this era ${ }^{29}$. In addition, with the start of the reign of the Umayyad Caliphate, the growth of the bourgeoisie (capitalism) could be observed in the Islamic world ${ }^{30}$. Landowners remained in the rural areas as the representatives of the state, whose main duty was to collect the taxes from farmers and send the taxes raisedfrom them to the central treasury. It must be noted that the landowners in the Islamic period, in addition to paying taxes also had to pay tribute which was a tax imposed on non-Muslim people implying their inferiority within the society. On the other hand, it should also be noted that the payment of tribute was a new phenomenon in the Islamic period which imposed more pressure on the famers from the landowner class.

\section{Archaeological Evidence of the Social Classes in the Sassanid Era and in Early Islam}

The three main fire temples that were exclusive to the nobles were: Azar-Farnbagh for the clergy, Azar-Goshasb for the warriors, and Azar-Barzin-Mehr for the nobles ${ }^{31}$. The existence of three fire temples for three different classes was a point of great importance as it seems the other temples of the Sassanid era were not intended for a specific group of people. In a letter by Tenser, he spoke of the social classes of the Sassanid era which considered the king as being the first member of the members of the religion and rulers, clergy, and educators who were included within this same group. The second group of the religion were the warriors who were divided into two groups, cavalry and infantry. The third group of the religion included the writers, treatise and audit writers, physicians, poets, and astronomers. The fourth group was called "Mahneh" which refers to farmers,

\footnotetext{
Ravandi 1977, 10-11.

26 See for example Bulliet 1994 passim.

Dinvari 2007, 314.

28 El-Maverdi 1994, 143.

29 Ravandi 2003, 50.

30 Ravandi 2003, 58.

31 Khord-e Avesta 1976, 43.
} 
servants, and merchants. The significant point about this letter is that it considers these four stratifications as forming a part of the religion ${ }^{32}$.

Sassanid and early Islam cities are one of the main resources available for the investigation of Iran's social structure during this period. One could mention the division of the city space into three sectors and the adherence to the hierarchical model of accommodating thepopulation in the three sectors of: fort or castle, sharestan (nobles' place), and outer city space where there were the gardens and the residences of the common people ${ }^{33}$. This model was a reflection and manifestation of the social system governing Sassanid era society. The study of Islamic era cities shows that city spatial model of the Sassanid era which consisted of fort, sharestan, and outer city continued. It seems that the reason for the continuity of this model was its effectiveness, as in the castles, the status of the king-citadel and religious places like the mosques are stressed and the security of the state treasury is maintained. Also the sharestan is surrounded by fortified walls which provided a secure space for the life of the citizens. This cohesion influenced the social relations of the citizens and provided the possibility for the king or the ruler to easily monitor the residents. On the other hand, industrial and agricultural activities which required wide spaces were kept outside the walls of the sharestan so that the congestion, pollution, and stress resulting from such activities are not passed into the residential areas. In the Islamic era due to the order of the Caliph Omar Ibn Al-Khattab, Muslims refused to settle in the captured cities $^{34}$. The reason for the reconstruction of the old cities and the emergence of new ones could be searched for in the social division of labor. The existence of cities brought about more social divisions of labor and also the separation of agricultural products from artisanal products although this division was not complete. In Iran the artisans were divided into two groups, the urban artisans and the rural ones. The existence of these artisans is the reason for the differences in the newly built cities from those of the time of slavery. After the Sassanid era, cities turned into centers of great people and centres of political activities ${ }^{35}$.

This issue is also traceable in the archaeological finds. For instance in the western city of Aranva Bidgol, a Sassanid city of the region, the western and the northwestern parts were evacuated and construction was concentrated in other directions during the Islamic period ${ }^{36}$. This same response is quite clearly visible in the city of Darabgerd, in that in early Islam the Sassanid city was evacuated and the main residences were moved to its northern location ${ }^{37}$. Similarly, for the Sassanid and early Islam city of Meymeh near Isfahan and Azan village, finds of Islamic pottery are only in the southern parts of the city, none could be found in the northern parts. Perhaps the main reason for this shift in the cities of early Islam was the removal of the common class system in the Sassanid period which made this change much easier.

The subject of social classes in the Sassanid cities is approachable from the perspective of the utopian city of Varjamkard. The name refers to a rampart that was built by Jamshid. According to the Vandidad story, Jamshid built "Var" which is a cave or city to protect a selection of creatures against the severe snow and cold that occurred in his time. Whenever the concept of a Iranian

\footnotetext{
Boyce 1968.

Habibi 2007, 33.

Oryan 1995, 179.

Ravandi 2003, 49.

36 Karimian - Javery 2010, 70.

37 Karimian - Seyedein 2011, 51.
} 
utopia is talked about, the city involves strong ramparts. Based upon another narration, Jamshid has made this city in order to protect a selection of people and useful animals that due to the harm caused by Malkus at the end of Ushidarin the fourth millennium would otherwise have been annihilated; thus from the protection of these ramparts they can repopulate the world with people, sheep, and other animals ${ }^{38}$. In the seventh Dinkard, it is stated about Varjamkard that Jamshid in his kingdom made both animal and human immortal, the water non-dryable, and the stews and foods incorruptible, he also made the world into a heaven and through Ahura-Mazda's command during the Malkusan winter, he built Varjmakard and protected the people from annihilation $\left(7^{\text {th }}\right.$ Dinkard, $1^{\text {st }}$ chapter, paragraphs 20-25). In some manuscripts, this deed of Jamshid is compared to those of Noah and of Suleiman. In the ideal society of the period of Jamshid, as a king, he enjoyed all the unique features such as: elegance, power, divine charisma, long life, the famous cup of divination, love and compassion, justice and equity, and others. According to the Iranian book of Bundahishn, Varjamkard amongst the Persians is located in Suva beneath a mountain that is called Jamgan after the king's name Jamshid. The city is the land of prosperity and happiness and a heaven hidden from the world's eyes, it is reminiscent of the memories that Iranians had of their most ancient birthplace $^{39}$. In this utopian city, the family, religion, and the state were the main institutions. The city is divided into three parts: the upper part for the clergy, the middle part for the warriors, and the third part for the commoners (farmers and shepherds). The number of the population that were commoners was 1000 families or 2000 persons, who are accommodated in the lower city, in 10 neighborhoods; while the population of warriors is 600 families or 1200 persons who are accommodated in the middle part of the city in six neighbourhoods. There are three hundred (300) clergy or 600 persons who were accommodated in the upper part of the city ${ }^{40}$. As is evident, the class system dominates the city of Varjamkard and this model was repeated again with exactly the same form in the Sassanid cities. We drew the Sassanid social classes and came up with a pyramid shape (fig. 1) which is also true concerning the city of Varjamkard. When the number of routes, neighborhoods, and the population of this city is considered, the resulting shape is in accord with the pyramid shape of Sassanid era cities.

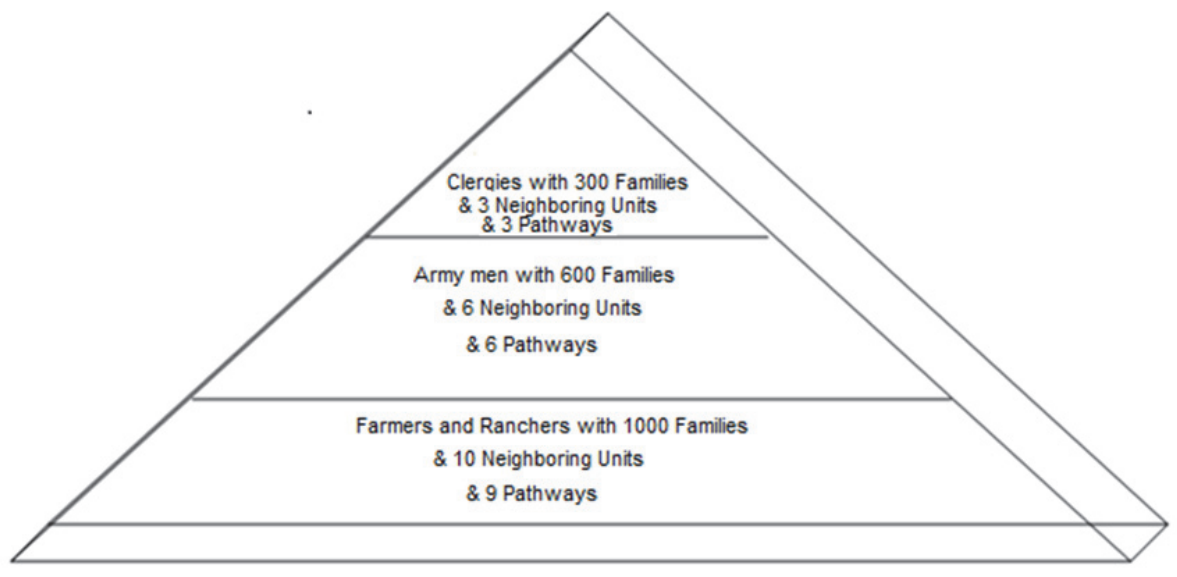

Fig 2. The Social Classes in the City of Varjamkard

38 Bahar 1990, 243.

39 Bahar 1990, 142.

40 Saeid Niya 1995. 
Metal objects form the other important group of archaeological finds of this period of transition, from the Sassanid to the early Islamic period. The material used for metal objects in early Islam differed from those employed by the Sassanids, as in early Islam most of the metal objects were made of bronze rather than of silver and it is likely that this issue is related to the ban on the use of valuable metals. However, from the social structure point of viewone can also investigate the issue of material change in the metal objects. According to what was described before, in early Islam some thoughts appeared that were against the prevailing social classes and the discrimination that was consequent upon this system. The way that such thoughts were implemented in the cities of early Islam were investigated and it seems that this issue is related to the use of metals in that era. The rulers implemented this through the use of bronze which was cheaper and more accessible than silver for the common people. By doing so, they intended to bring the social classes closer together so that the Sassanid social classes and the divisions they embodied were wrecked.

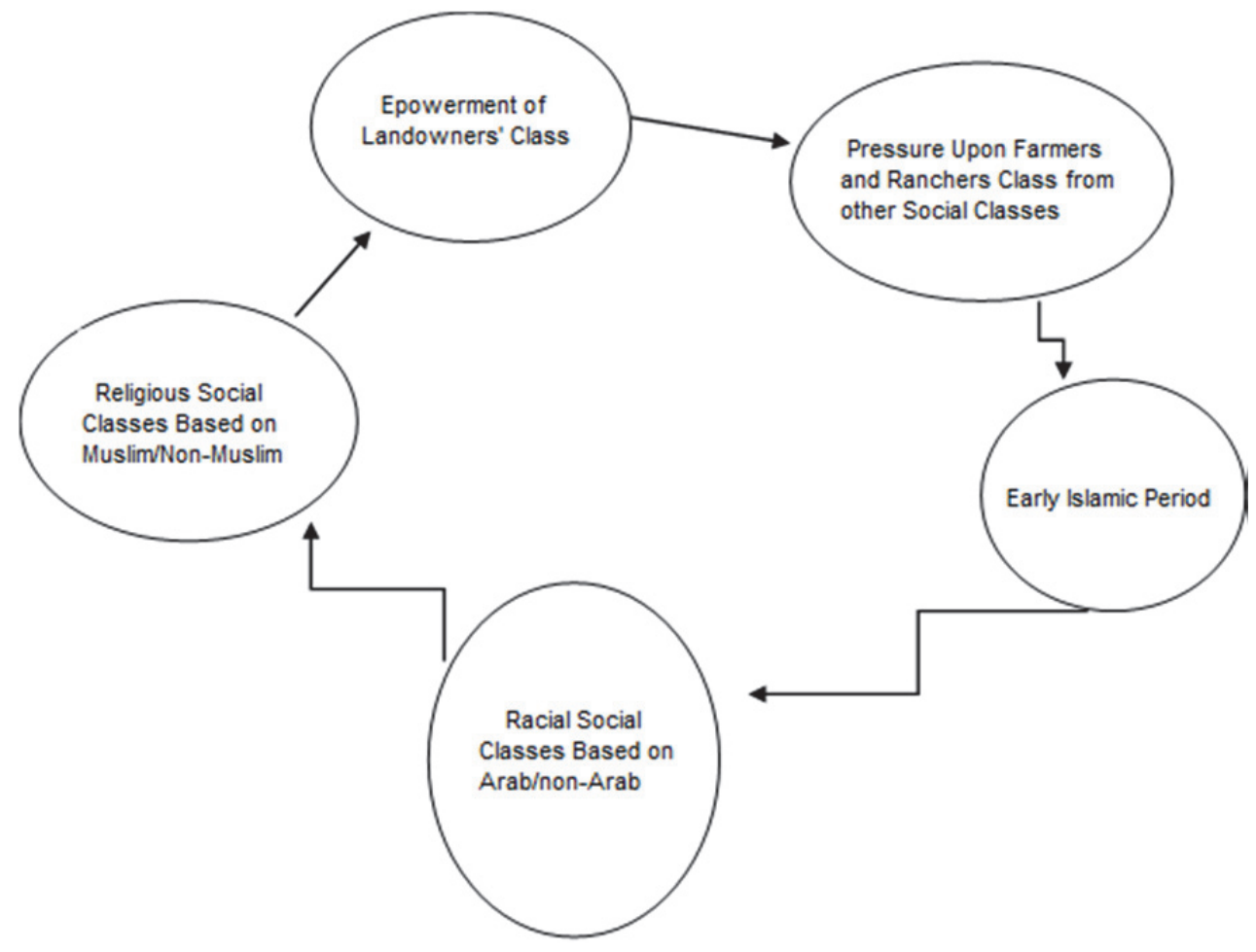

Fig 3. Social Conditions of Early Islam (NB Empowerment of the - Pressure on the)

\section{Conclusion}

The use of political power to enforce the social organization favored by the Zoroastrian priesthood on the society, resulted in the dissatisfaction of a segment of that society ${ }^{41}$. As a result of the domination of these values and norms of the Sassanid era and also the continuity of the unequal distribution of political, economic, and social privileges, the Mani and the Mazdak movements emerged to resist such inequalities ${ }^{42}$. The joining of various social strata to the Mazdakian movement and the turmoil caused by it, and even the Mani movement, can be considered as the Pre-Islam efforts to eliminate the social class system of that era and also to lessen the resultant pressure from the system

$41 \quad$ Karimian - Moghimi 2014, 40.

42 Sasanpur - Moftakhari 2012, 81. 
on the majority of the people. Therefore, based upon what has been mentioned above, the main reason for accepting Islam by the Iranian people was freedom from the pressures caused by the upper social classes of the Sassanian state. This social pressure may have been removed only for a short period of time and with the beginning of Umayyad rule as mentioned above, the farmers, forming the lower classes of a society that had a large population again felt the pressure from the upper social classes. In the Umayyad period, in addition to the former classes' subject, the issue of Arab and non-Arab races put a great deal of pressure on the Iranian farmers. In addition, the farmers as the most populous class in Iran in early Islam, witnessed much pressure upon themselves from the landowners' social class because they were directly controlled and ordered by the landowners' social class. Therefore, an agrarian-based or landownership system could be observed in the early Islamic period of Iran. However, according to both historical and archaeological finds, in addition to the pressures from the landowners, pressures from other social classes can be seen imposed upon the farmers. 


\section{BIBLIOGRAPHY}

Al-Tabari 1881

Ansari 1960

Bahar 1990

Benveniste 1932

Biro 1987

Boyce 1968

Bulliet 1994

Coen 1993

Dinvari 2007

Dumezil 1958

Dumont 1990

El-Maverdi 1994

Ferdowsi 2006

Habibi 2007

Karimian 2008

Karimiyan - Jāveri 2010

Karimian - Seyedein 2011

Karimian - Moghimi 2014

Kazazi 2006

Moinifar 2012

Oryan 1995

Panoff - Bern 1989

Pour Davoud 1988

Pour Davoud - Frahwashi 1998
A. J. F. M. ibn-Jarir Al-Tabari, The History of al-Tabari. Tehran 1881.

G. Ansari, Muslim Caste in Uttar Pradesh. Lucknow 1960.

M. Bahar, Faranbaghdadegi, Bundahesh. Tehran 1990.

E. Benveniste, "Les Classes Socials dans la tradition Avestic". Asiatique VI (1932) 117-134.

A. Biro, Culture of Social Sciences. Tehran 1987.

M. Boyce, The Letter of Tansar. Rome 1968.

R. W. Bulliet, Islam: The View from the Edge. New York 1994.

B. Coen, Introduction to the Sociology. Tehran 1993.

A. A. D. Dinvari, Akhbar al-Taval. Tehran 2007.

G. Dumezil, L'ideologie Tripartie des Indo-Europeens. Bruxelles 1958.

L. Dumont, Caste System in India. London 1990.

I. El-Maverdi, el-Ahkâmu's-Sultaniyye. İstanbul 1994.

A. Ferdowsi, Shahnameh: The Persian Book of Kings. New York 2006.

M. Habibi, From Share to Urban: A Historical Analysis of the City and its Physical Appearance, Reflection. Tehran 2007.

H. Karimian, "Iranian Society in the Sasanian Period". Eds. D. Kennet L. Paul, Current Research in Sasanian Archaeology, Art and History. Oxford (2008) 99-106.

H. Karimiyan - M. Jāveri, "Vigol and Harāskān, Two Cities; A Study Based on Archaeological Data in Transformation from Sassanid Era to the Islamic Period Relying Upon Archeological Data”. Journal of Archaeological Studies I/2 (2010) 63-83.

H. Karimian - S. Seyedein, "Iranian Cities after the Collapse of Sasanian Kingdom: A Case Study of Darabgerd”. Intl. J. Humanities XVIII/2 (2011) 51-62.

H. Karimian - N. Moghimi, "Sasanian Emperors as the Pioneers of Globalization: An Investigation on the Ideas of Globalization in Ancient Iran”. Journal of Historical Sociology VI/3 (2014) 31-55.

J. Kazazi, The Edition and Interpretation of Shahname of Ferdowsi, vol. I. Tehran 2006.

H. Moinifar, "Investigation of the Roots of the Caste System in India". Journal of Subcontinent Researches 4/10 (2012) 91-108.

M. Oryan, Proceedings of the Second Congress of Urban and Architectural History: Volume 1, Cultural Heritage Organization of Iran Publication. Tehran 2000.

M. Panoff - M. Bern, Cultural Ethnology. Tehran 1989.

E. Pour Davoud, Yashtha. Tehran 1988.

E. Pour Davoud - Frahwashi, Yasna. Tehran 1998. 
Ravandi 2003

Ravandi 1997

Saeidi Madani 2011

Saeid Niya 1995

Sasanpur - Moftakhari 2012

Khord-e Avesta 1976

Weber 2003
M. Ravandi, Social History of Iran. Tehran 2003.

M. Ravandi, Iran Social History. Tehran 1977.

S. M. Saeidi Madani, "The Study of Caste-Class System in Rig - Veda and Avesta”. Social Development \& Welfare Planning Journal 5 (2011) 61-90.

A. Saeid Niya, Urban Thought Mythical in First Iranian Cities. Tehran 1995.

S. Sasanpur - H. Moftakhari, "The Change of Social Stratification System in Iran from the Fall of Sasanian to the End of Omavids". Social History Research Journal 1/1 (2012) 79-96.

Khorde Avesta. Trans. J. 1. M. Kaikhusroo, J. Asa, M. Nawabi - B. Faravashi. Shiraz 1976.

M. Weber, Religion, Power, Community. Tehran 2003. 